\title{
Synthesis and Antibacterial Activity of Thiophenes
}

\author{
Wedad M. Al-Adiwish", W.A. Yaacob*, D. Adan ${ }^{*}$, I. Nazlina ${ }^{\#}$ \\ "School of Chemical Sciences and Food Technology, Universiti Kebangsaan Malaysia, 43600 Bangi, Selangor, Malaysia. \\ E-mail:we80dad@yahoo.com;wanyaa@ukm.my;dalinaadan@gmail.com \\ ${ }^{\#}$ School of Biosciences and Biotechnology, Universiti Kebangsaan Malaysia, 43600 Bangi, Selangor, Malaysia \\ E-mail:nazlina@ukm.my
}

\begin{abstract}
Bis(methylthio)methylene]propanedinitrile 1a reacted in one-pot successively with piperidine, sodium sulfide, chloroacetonitrile, and potassium carbonate to afford 3-amino-5-(1-piperidinyl)-2,4-thiophenedicarbonitrile 2a. Similar reaction using the last three reagents with ethyl 2-cyano-3,3-bis(methylthio)acrylate $1 \mathrm{~b}$ produced ethyl 4-amino-5-cyano-2(methylthio)thiophene-3-carboxylate $2 \mathrm{~b}$. The synthesized compounds were characterized by using FT-IR, ${ }^{1} \mathrm{H}-\mathrm{NMR}$, ${ }^{13} \mathrm{C}-\mathrm{NMR}$, and mass spectral data. Antibacterial activities of the synthesized compounds are also reported.
\end{abstract}

Keywords — Ketene dithioacetals; thiophenes; antibacterial activity.

\section{INTRODUCTION}

Thiophene and its derivatives constitute one of the major classes in heterocyclic chemistry. They have been shown to have interesting biological properties such as anticancer, ${ }^{[1]}$ antiviral, ${ }^{[2]}$ antitumor, ${ }^{[3]}$ anti-inflammatory, ${ }^{[4]}$ and antimicrobial. $^{[5]}$ Starting from thiophene derivatives, many thieno-fused bicyclic compounds such as thienopyridines, ${ }^{[6]}$ thienopyrimidines, ${ }^{[7]}$ and thienopyrroles ${ }^{[8],[9]}$ have been synthesized. El-Saghier et al. ${ }^{[10],[11]}$ have reported the syntheses and reactions of various thiophenes and fused thiophenes via ketene S,S- and N,S-acetals. In this work, we prepare new tetrasubstituted thiophenes $\mathbf{2 a}$ and $\mathbf{2 b}$ from ketene dithioacetals using one-pot four- or three -step procedures. ${ }^{[12 \mathrm{a}, \mathrm{b}]}$

\section{Methodology}

\section{A. Instrumentation}

All starting materials were purchased from Aldrich and Sigma and used without further purification. Melting points were determined using a hot stage Gallenkamp melting point apparatus. Infrared spectra were recorded on FTIR 8300 Shimadzu spectrophotometer using potassium bromide. ${ }^{1} \mathrm{H}$ - and ${ }^{13} \mathrm{C}-\mathrm{NMR}$ spectra in DMSO were recorded on Varian XL $500 \mathrm{MHz}$ using TMS as internal standard. Mass spectra were recorded on GC-MS QP2010 plus Shimadzu attached with DI2010-MS Shimadzu. TLC analysis was carried out on silica gel of Merck no. 5545.

\section{B. Synthesis of starting materials}

The starting materials of 2-[bis(methylthio)methylene] propanedinitrile 1a and ethyl 2-cyano-3,3-bis(methylthio) acrylate 1b were prepared (see Scheme 1) according to Sommen et al. ${ }^{[8],[14]}$ as follows.

\section{1). Synthesis of 2-[bis(methylthio)methylene] propane- dinitrile (1a)}

A mixture of malononitrile $(6.60 \mathrm{~g}, 0.1 \mathrm{~mol})$ and potassium carbonate $(11.31 \mathrm{~g}, 0.1 \mathrm{~mol})$ was dissolved in DMF $(110 \mathrm{ml})$ and the solution was stirred for $1 \mathrm{~h}$ at room temperature. After that, carbon disulfide $(7.60 \mathrm{~g}, 0.2 \mathrm{~mol})$ was added drop-wise to the mixture at $0^{\circ} \mathrm{C}$ for $15 \mathrm{~min}$. Then the reaction mixture was stirred at room temperature for $2 \mathrm{~h}$. Methyl iodide $(28.38 \mathrm{~g}, 0.2 \mathrm{~mol})$ was added drop-wise to the mixture at $0^{\circ} \mathrm{C}$ and stirred at room temperature for $4 \mathrm{~h}$. The precipitate was filtered, washed with water, and dried at room temperature until constant weight. The isolated solid was purified by recrystallization in ethanol.

\section{2). Synthesis of ethyl 2-cyano-3,3-bis(methylthio)acrylate} (1b)

A mixture of ethyl cyanoacetate $(11.31 \mathrm{~g}, 0.1 \mathrm{~mol})$ and potassium carbonate $(11.31 \mathrm{~g}, 0.1 \mathrm{~mol})$ was dissolved in DMF $(110 \mathrm{ml})$ and the solution was stirred for $1 \mathrm{~h}$ at room temperature. After $1 \mathrm{~h}$, carbon disulfide $(7.60 \mathrm{~g}, 0.1 \mathrm{~mol})$ was added drop-wise to the solution at $0^{\circ} \mathrm{C}$. The reaction mixture was stirred at room temperature for $2 \mathrm{~h}$. Methyl 
iodide $(28.38 \mathrm{~g}, 0.2 \mathrm{~mol})$ was added drop-wise to the solution at $0^{\circ} \mathrm{C}$ and stirred at room temperature for $24 \mathrm{~h}$. The precipitate was filtered, washed with water, and dried at room temperature until constant weight. The isolated solid was purified by recrystallization in ethanol.

\section{Synthesis of thiophenes}

The following is one-pot four- and three-step procedures for preparing $\mathbf{2 a}$ and $\mathbf{2 b}$ (as in Scheme 2).

\section{1). Preparation of 3-amino-5-(1-piperidinyl)-2,4- thiophenedicarbonitrile $2 \boldsymbol{a}$}

2-[Bis(methylthio)methylene]propanedinitrile 1a (0.01 mol) was dissolved in DMF $(15 \mathrm{ml})$, piperidine $(0.01 \mathrm{~mol})$ added, and the mixture was heated at $70^{\circ} \mathrm{C}$ for $75 \mathrm{~min}$. Then $\mathrm{Na}_{2} \mathrm{~S} .9 \mathrm{H}_{2} \mathrm{O}(0.01 \mathrm{~mol})$ was added and heated for $2 \mathrm{~h}$ at $70^{\circ} \mathrm{C}$. Chloroacetonitrile $(0.02 \mathrm{~mol})$ was added dropwise at $70^{\circ} \mathrm{C}$ and the reaction mixture was heated at $70^{\circ} \mathrm{C}$ for $2 \mathrm{~h}$. Then potassium carbonate $(0.02 \mathrm{~mol})$ was added and stirred at $70^{\circ} \mathrm{C}$ for $90 \mathrm{~min}$. The reaction mixture was poured onto water $(100 \mathrm{ml})$ with good stirring. The appearing precipitate was filtered, washed with water, and dried at room temperature until constant weight. The isolated solid 2a was purified by recrystallization in ethanol.

\section{2).Preparation of ethyl 4-amino-5-cyano-2- (methylthio)thiophene-3-carboxylate $2 \boldsymbol{b}$}

A 0.01 mol of ethyl 2-cyano-3,3-bis(methylthio) acrylate 1 b was dissolved in DMF $(15 \mathrm{ml})$. The $\mathrm{Na}_{2} \mathrm{~S} .9 \mathrm{H}_{2} \mathrm{O}(0.01$ mol) was added to solution and heated for $2 \mathrm{~h}$ at $70^{\circ} \mathrm{C}$. Then chloroacetonitrile $(0.02 \mathrm{~mol})$ was added drop-wise to mixture at $70^{\circ} \mathrm{C}$ and heated at $70^{\circ} \mathrm{C}$ for $2 \mathrm{~h}$. Finally potassium carbonate $(0.02 \mathrm{~mol})$ was added to mixture and stirred at $70^{\circ} \mathrm{C}$ for $90 \mathrm{~min}$. Then, the mixture was poured onto water $(100 \mathrm{ml})$ with good stirring. The appearing precipitate was filtered, washed with water, and dried at room temperature until constant weight. The isolated solid of $\mathbf{2 b}$ was purified by recrystallization in ethanol.

\section{Determination of antibacterial activity}

The new synthesized compounds $\mathbf{2 a}$ and $\mathbf{2 b}$ were screened in vitro for their antibacterial activity against Gram-positive bacteria (Staphylococcus aureus and Bacillus subtilise) and Gram-negative bacteria (Escherichia coli and Klebsiella pneumonia) by agar disc-diffusion technique. ${ }^{[13]}$ The bacteria were maintained on nutrient agar and antibacterial test was performed using Mueller-Hinton agar. A $50 \mathrm{mg}$ of each compound was dissolved in $1 \mathrm{ml}$ of DMSO to give solutions of $50 \mathrm{mg} / \mathrm{ml}$. A sterile disc with $10 \mu \mathrm{l}$ of each compound was applied on bacterial lawn. Streptomycin $10 \mu \mathrm{g}$ was used as positive antibiotic control for antibacterial activity. After $18-24 \mathrm{~h}$ of incubation at $37^{\circ} \mathrm{C}$, the diameter of inhibition zone was measured in $\mathrm{mm}$. DMSO was used as negative control.

\section{RESULTS AND DISCUSSION}

We report herein the synthesis of new tetrasubstituted thiophenes $\mathbf{2 a}$ and $\mathbf{2 b}$ from ketene dithioacetals. The first step is preparing the ketene dithioacetals from condensation of activated methylene in malononitrile and ethyl cyanoacetate with carbon disulfide in the presence of a base potassium carbonate to obtain the intermediate of ketene S,S-acetal salts; their alkylation with methyl iodide leads to the formation of corresponding 2[bis(methylthio)methylene]propanedinitrile 1a and ethyl 2cyano-3,3-bis(methylthio)acrylate 1b (Scheme 1) in high yields as reported in literatures. ${ }^{[8],[14]}$

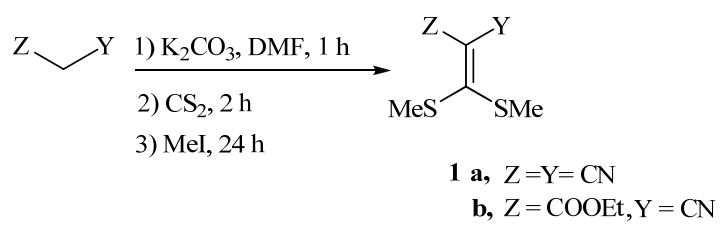

Scheme 1. Preparation of ketene dithioacetals $\mathbf{1 a}$ and $\mathbf{1 b}$

These ketene dithioacetals $\mathbf{1 a}$ and $\mathbf{1 b}$ were used to synthesize new tetrasubstituted thiophenes $\mathbf{2 a}$ and $\mathbf{2} \mathbf{b}$ in accordance to the literature procedure ${ }^{[12 a, b]}$ as follows (Scheme 2). Compound 1a was reacted with piperidine in $\mathrm{DMF}$ and heated at $70^{\circ} \mathrm{C}$ for $75 \mathrm{~min}$ to form intermediate ketene N,S-acetal $\mathbf{1 a}^{\mathbf{1}}$ (Scheme 3); then $\mathrm{Na}_{2} \mathrm{~S}$ was added and heated at $70^{\circ} \mathrm{C}$ for 75 min to give ketene N,S-acetal salt $\mathbf{1 a}^{\mathbf{2}}$. After that, chloroacetonitrile was added and heated for $2 \mathrm{~h}$ to yield ketene N,S-acetal $\mathbf{1 a}^{\mathbf{3}}$. Finally, potassium carbonate was added in order to cyclize $\mathbf{1} \mathbf{a}^{\mathbf{3}}$ into $\mathbf{2} \mathbf{a}$ in high yield (73.70\%). Also compounds $\mathbf{1 b}$ was dissolved in DMF, and then $\mathrm{Na}_{2} \mathrm{~S}$ was added and heated at $70^{\circ} \mathrm{C}$ for $75 \mathrm{~min}$ to yield $\mathbf{1 b}^{\mathbf{1}}$. After that, chloroacetonitrile was added and heated for $2 \mathrm{~h}$ to produce $\mathbf{1} \mathbf{b}^{\mathbf{2}}$. Finally, potassium carbonate was added for cyclization to give $\mathbf{2 b}$ in low yield (22.31\%).

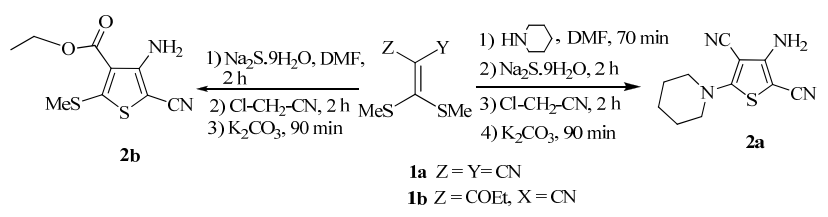

Scheme 2. Preparation of thiophenes $\mathbf{2 a}$ and $\mathbf{2 b}$

In general, the probable mechanism for formation of thiophenes $2 \mathrm{a}$ and $2 \mathrm{~b}$ involves the formation of the intermediate thiolates $1 \mathrm{a} 2$ and $1 \mathrm{~b} 1$ upon addition of sodium sulfide into the pot and liberating one equivalent of methyl thiolate (Scheme 3). Two equivalent of chloroacetonitrile were added whereby the first was consumed by the methyl thiolate and the second by the intermediate thiolate salt that leads to the thioacetals $1 \mathrm{a} 3$ and $1 \mathrm{~b} 2$. Finally, potassium carbonate was added to for cyclization of $2 \mathrm{a}$ and $2 \mathrm{~b}$.

The spectral data of the obtained products are in accordance with the proposed structures as explained below. The IR spectra of $2 \mathrm{a}$ and $2 \mathrm{~b}$ showed bands at 3423$3201 \mathrm{~cm}-1$ for NH2 groups. The $1 \mathrm{H}-\mathrm{NMR}$ spectra of compounds $2 \mathrm{a}$ and $2 \mathrm{~b}$ showed broad singlets at $\delta 6.49,6.79$ ppm for the respective NH2 groups. The 13C-NMR spectra showed peak at $76.63 \mathrm{ppm}$ for S-C-CN of compound $2 \mathrm{a}$ and peaks at 157.70 and $157.59 \mathrm{ppm}$ for $\mathrm{C}-\mathrm{NH} 2$ of respective compounds $2 \mathrm{a}$ and $2 \mathrm{~b}$. The elemental analysis of compounds $2 \mathrm{a}$ and $2 \mathrm{~b}$ are also in accordance with the 
proposed structures. Moreover, the mass spectra of each compound were compatible with their molecular formulas.

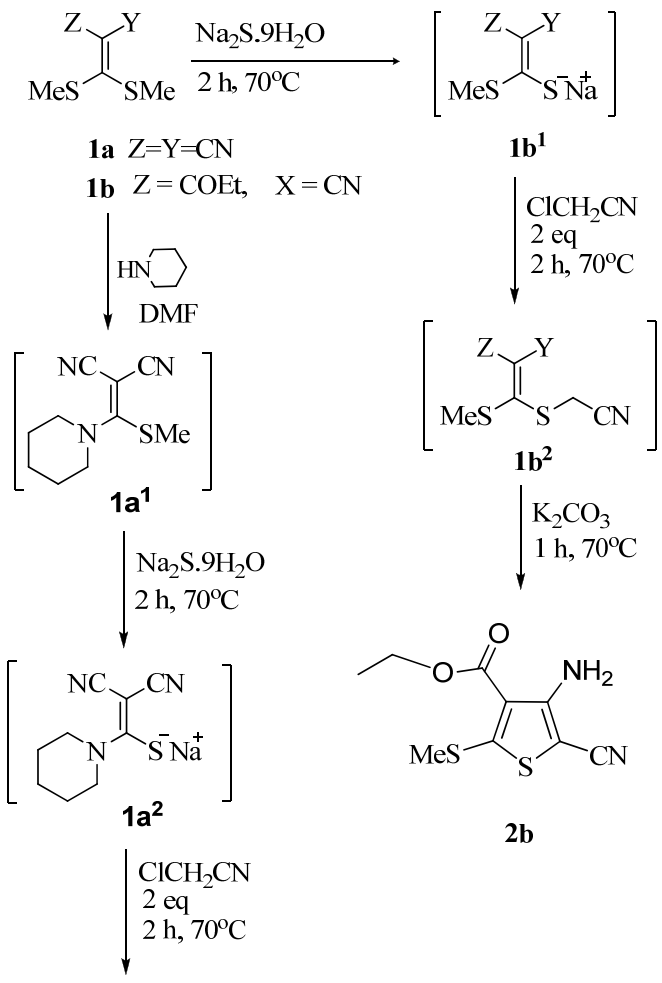<smiles>[Y]C(=O)C1CCCCN1c1sc(C#N)c(N)c1C#N</smiles>

Scheme 3 . The most likely intermediates formed during the formation of thiophenes $\mathbf{2} \mathbf{a}$ and $\mathbf{2} \mathbf{b}$

\section{A. Spectral Data}

1). 3-Amino-5-(1-piperidinyl)-2,4-thiophenedicarbonitrile (2a): Brown crystals; Mp: $220-222^{\circ} \mathrm{C}$; Yield: $73.70 \%$; FTIR $\left(\mathrm{KBr}, \mathrm{cm}^{-1}\right): v 3396,3338,3244,2934,2857,2174,1649$, $1600,1549,1514,1393,1136,1008,513 ;{ }^{1} \mathrm{H}-\mathrm{NMR}(500$ $\mathrm{MHz}, \mathrm{DMSO}): \delta 1.58$ (br, $6 \mathrm{H}, 3 \mathrm{CH}_{2}$ ), 3.67 (br, $4 \mathrm{H}, 2 \mathrm{CH}_{2-}$ $\mathrm{N}), 6.49$ (br, $\left.2 \mathrm{H}, \mathrm{NH}_{2}\right) ;{ }^{13} \mathrm{C}-\mathrm{NMR}(100 \mathrm{MHz}, \mathrm{DMSO}): \delta$ 23.21 $\left(\mathrm{CH}_{2}\right), 25.14\left(2 \mathrm{CH}_{2}\right), 51.58\left(2 \mathrm{CH}_{2}-\mathrm{N}\right), 59.81(\underline{\mathrm{C}}-\mathrm{CN})$, 76.63 (ㄷ-CN), 115.65, 116.21 (2CN), 157.70 ( - $\left.-\mathrm{NH}_{2}\right)$, 166.07 (S-C-N); DIMS (m/z): found 232.00 (calc. for $\mathrm{C}_{11} \mathrm{H}_{12} \mathrm{~N}_{4} \mathrm{~S} \mathrm{M}^{+}$requires 232.30). Anal. calcd. for $\mathrm{C}_{11} \mathrm{H}_{12} \mathrm{~N}_{4} \mathrm{~S}$ : C 56.87, H 5.21, N, 24.12\%; found: C 56.25, H 5.23, N $24.28 \%$.

2). Ethyl 4-amino-5-cyano-2-(methylthio)thiophene-3carboxylate (2b): Brown pale; Mp: $172-173^{\circ} \mathrm{C}$; Yield: 22.31\%; FT-IR (KBr, cm $\left.{ }^{-1}\right): v$ 3423, 3329, 3201, 2974, 2925 , 2187, 1684, 1614, 1533, 1455, 1310, 1208, 1024, 783, 511; ${ }^{1} \mathrm{H}-\mathrm{NMR}$ (500 MHz, DMSO): $\delta$ 1.28-1.31(t, 3H, $\mathrm{CH}_{3}$ ), 2.55 (s, 3H, $\mathrm{SCH}_{3}$ ), 4.27-4.29 (q, 2H, $\left.\mathrm{OCH}_{2}\right), 6.79$ (s, 2H, $\mathrm{NH}_{2}$ ); ${ }^{13} \mathrm{C}$ NMR (100 MHz, DMSO): $\delta 14.51\left(\mathrm{CH}_{3}\right), 17.08\left(\mathrm{SCH}_{3}\right)$, $61.53\left(\mathrm{CH}_{2}-\mathrm{O}\right), 73.77$ ( $\left.\mathrm{C}-\mathrm{CN}\right), 113.02(\mathrm{CN}), 115.27$ (드- $\left.\mathrm{CO}\right)$ $157.59\left(\mathrm{C}-\mathrm{NH}_{2}\right), 161.22\left(\mathrm{~S}-\underline{\mathrm{C}}-\mathrm{SCH}_{3}\right), 162.76(\mathrm{C}=\mathrm{O})$; DIMS $\left(\mathrm{m} / \mathrm{z}\right.$ ): found 242.20 (calc. for $\mathrm{C}_{9} \mathrm{H}_{10} \mathrm{~N}_{2} \mathrm{O}_{2} \mathrm{~S}_{2} \mathrm{M}^{+}$requires
242.32). Anal. calcd. for $\mathrm{C}_{9} \mathrm{H}_{10} \mathrm{~N}_{2} \mathrm{O}_{2} \mathrm{~S}_{2}$ : C 44.61, $\mathrm{H} 4.16, \mathrm{~N}$ $11.56 \%$; found: C 44.89, H 4.36, N $11.60 \%$.

\section{B. Antibacterial activity of the compounds}

The results for antibacterial activity are depicted in Table 1. It is revealed that compounds $\mathbf{2 a}$ and $\mathbf{2} \mathbf{b}$ showed limited antibacterial activity in all the bacteria tested with $\mathbf{2 a}$ exhibited bigger inhibition zones compared to $\mathbf{2 b}$. DMSO showed no inhibition zone.

TABLE I

INHIBITION ZONES (MM) AS A CRITERION OF ANTIBACTERIAL ACTIVITY OF THE NEWLY SYNTHESIZED COMPOUNDS.

\begin{tabular}{|l|l|l|l|l|}
\hline \multirow{2}{*}{ Bacteria } & \multicolumn{2}{|c|}{ Inhibition zones (mm) } \\
\cline { 2 - 5 } & $\mathbf{2 a}$ & $\mathbf{2 b}$ & DMSO & Streptomycin \\
\hline B. subtilis & - & - & - & 25 \\
\hline S. aureus & 9 & 7 & - & 13 \\
\hline E. coli & 7 & - & - & 25 \\
\hline K. pneumoniae & - & - & - & 25 \\
\hline
\end{tabular}

\section{IV.CONCLUSION}

In summary, we have successfully synthesized tetrasubstituted thiophenes from ketene dithioacetals using one-pot four- or three -step procedures under moderate conditions. These compounds can be used as intermediates in synthesizing various thieno-fused bicyclic compounds. The synthesized compounds showed moderate antibacterial activity.

\section{ACKNOWLEDGMENT}

We would like to thank Ministry of Higher Education Malaysia and Universiti Kebangsaan Malaysia for research grant of UKM-GGPM-KPB-098-2010. A scholarship from the Libyan Government to Wedad M. Al-Adiwish is greatly appreciated.

\section{REFERENCES}

[1] D. J. Brown, "Pyrimidines and Their Benzo Derivatives, in Comprehensive Heterocyclic Chemistry,” (Ed. A. R. Katritzky and C. W. Rees), Pergamon Press, Oxford, Vol. 3, pp. 443, 1984.

[2] B. Roth and C. Cheng, "Diaminopyrimidines, in Progress in Medicinal Chemistry, " (Eds. G. B. Ellis and G. E. West), Elsevier Biomedical Press, New York, Vol. 19, pp. 267, 1982.

[3] M. S. A. E.-A. El-Gaby, S. G. Abdel-Hamide, M. M. Ghorab and S. M. El-Sayed, "Synthesis and anticancer activity in vitro of some new pyrimidines," Acta Pharm., vol. 49, pp. 149-158, 1999.

[4] C. R. Petrie, H. B. Cottam, P. A. Mckernan, R. K. Robins and G. R. Revankar, "Synthesis and biological activity of 6-azacadeguomycin and certain 2,4,6-trisubstituted-pyrazolo[3,4- $d]$-pyrimidine ribonucleosides," J. Med. Chem., vol. 28, pp. 1010-1016, 1985.

[5] M. N. Nasr and M. M. Gineinah, "Pyrido[2,3- $d$ ]pyrimidines and pyrimido[5',4':5,6]-pyrido[2,3- $d]$ pyrimidines as new antiviral agents: Synthesis and biological activity," Arch. Pharm., vol. 335, pp. 289295, 2002.

[6] J. Campos, E. Anon, M. Carmen Malo, and M. A. Rodriguez, "Aversatile synthesis of pyrrolo-, Furo- and Thiono pyridines via photocyclization of 3-amino-2- alkene imines in an acid medium," Tetrahedron, vol. 55, pp. 14079, 1999.

[7] B. Abdel-Fattah, M. M. Kandeel, M. Abdel-Hakeem and Z. M. Fahmy, "Synthesis of Certain Fused Thienopyrimidines of Biological Interest," Journal of the Chinese Chemical Society, vol. 53, pp. 403-412, 2006. 
[8] G. Sommen, A. Comel and G. Kirsch, "Preparation of thieno[2,3b]pyrroles starting from ketene-N,S-acetals," Tetrahedron, vol. 59 , pp. 1557-1564, 2003

[9] A. A. Shimkin, A. K. Mailian, V. Z. Shirinian, and M. M. Krayushkin,"Synthesis of $1 \mathrm{H}-$ and 3H-[1]Benzothieno[3,2b]pyrroles," Synthesis, vol. 17, pp. 2706-2710, 2007.

[10] M. M. El-Saghiera, F. S. Matoughb, M. F. Farhatb, N. A. Salehb, K. M. Kreddanc, S. O. El-Tierb , and H. B. Hussienc, "Synthesis and Biological Evaluation of Some New Thienopyridine and Thienopyrimidine Derivatives," Jordan Journal of Chemistry, Vol. 3 No. 3, pp. 223-232, 2008.

[11] A.M. M. El-Saghier, "A Simple Synthesis of Some New Thienopyridine and Thienopyrimidine Derivatives," Molecules, 7, 756-766, 2002.
[12] D. Thomae, E. Perspicace, Z. Xu, D. Henryon, S. Schneider, S Hesse, G. Kirsch, and P. Seck, "One-pot synthesis of new 2,4,5 trisubstituted 1,3-thiazoles and 1,3-selenazoles," Tetrahedron, vol. 65, pp. 2982, 2009; (a). D. Thomae, E. Perspicace, D. Henryon, Z. $\mathrm{Xu}$, S. Schneider,"One-pot synthesis of new tetrasubstituted thiophenes and selenophenes," Tetrahedron, vol. 65, pp. 10453 10458, 2009.

[13] A.W. Bauer, W.M.M. Kirby, J.C. Serris, and M. Turck, "Antibiotic susceptibility testing by a standardized single disk method," American Journal of Clinical Pathology., vol. 45, pp. 493-496, 1966.

[14] G. Sommen, A. Comel, and G. Kirsch, "An improved method for the synthesis of aminothiophenes precursors of thieno[2,3-b]pyrrole," Tetrahedron Lett., vol. 43, pp. 257, 2002. 